\title{
HYBRID SULFONYLUREA-LINKED CHALCONOIDS AS ANTIDIABETIC AGENTS: EVALUATION OF ANTIHYPERGLYCEMIC EFFECTS IN STREPTOZOTOCIN- INDUCED TYPE 2 DIABETIC RATS
}

\author{
D. Bhagya Raju ${ }^{1, *}$, A. Vasudeva Rao ${ }^{2}$ and Y. Rajendra Prasad \\ ${ }^{1}$ Pharmaceutical Chemistry/ Pharmacology Division, Andhra University College of \\ Pharmaceutical Sciences, Visakhapatnam, 530003, Andhra Pradesh, India \\ ${ }^{2}$ Pharmaceutical Chemistry Department, School of Pharmacy, International Medical University, \\ 18 Jalan Jalil Perkasa, Bukit Jalil, 57000 Kuala Lumpur, Malaysia \\ *E-mail : bhagyaraj_au@rediffmail.com
}

\begin{abstract}
The proposed investigation was carried out to evaluate the antihyperglycemic potential and to explore the structureactivity relationship (SAR) of a series of 28 hybrid sulfonylurea-linked chalconoids using streptozotocin-induced type 2 diabetic rats. Among all the compounds tested, compound SC 21 exhibited remarkable antidiabetic activity. Keywords: Hybrid sulfonylurea-linked chalconoid; the antihyperglycemic effect, type 2 diabetes.

(C) RASĀYAN. All rights reserved
\end{abstract}

\section{INTRODUCTION}

Drug discovery is a continuous process which, depending on the strategy used, typically comprises several discrete stages: target identification and validation; assay development; screening (whole cell or molecular target-based) to identify hits; procurement/synthesis and assessment of analogues to develop structure-activity relationships (SAR) and identify leads; iterative medicinal chemistry to optimize leads; and preclinical development prior to clinical evaluation ${ }^{1}$. Diabetes defines a group of metabolic diseases categorized by hyperglycemia and pancreatic $\beta$-cell dysfunction. Type 2 diabetes mellitus (T2DM) is a chronic metabolic disease characterized by high blood sugar levels resulting from the reduction of insulin secretion and/or insulin resistance ${ }^{2}$. It is widely known that elevation of blood glucose caused by disruption of carbohydrate, protein and fat metabolism can lead to diabetic complications in several organs and tissues, including eyes, kidneys, nerves and blood vessels ${ }^{3}$. Although various clinically used antidiabetic drugs are available, it has been shown that current clinical management is not adequately addressed by existing therapies, and therefore an exploration of the novel scaffolds as antidiabetic agents are still in demand ${ }^{4}$.

The search for new drugs with antidiabetic activity remains a focused area of worldwide research. Chalcones are naturally occurring bichromophoric compounds captivated significant attention due to its diverse range of pharmacological properties such as heat shock protein-inducer ${ }^{5}$, antimitotic ${ }^{6}$, antiproliferative $^{7}$, antibacterial ${ }^{8}$, pro-angiogenic ${ }^{9}$, antiviral ${ }^{10}$, antioxidant ${ }^{11}$, leishmanicidal ${ }^{12}$, antiinflammatory ${ }^{13}$, anti-Alzheimer's ${ }^{14}, \quad \beta$-secretase inhibitors ${ }^{15}$, spasmolytic $^{16}$, antimicrobial ${ }^{17}$, acetylcholinesterase inhibitors ${ }^{18}$, antimycobacterial ${ }^{19}$, suppressor of COX-2 expression ${ }^{20}$, antimalarial ${ }^{21}$, anti-apoptotic ${ }^{22}$, cytotoxic ${ }^{23}$, anticancer ${ }^{24}$, and anti-prostatic ${ }^{25}$. Similarly sulfonylurea moiety has also gained privileged status due to its biological activity profiles which includes hypoglycemic ${ }^{26}$, peroxisome proliferator-activated receptor $\gamma$ agonistic ${ }^{27}$, antimicrobial ${ }^{28}$, herbicidal ${ }^{29}$, selective EP4 receptor antagonists $^{30}$, selective bombesin receptor subtype-3 (SCS-3) agonist $^{31}$, antagonists of the CXCR2 receptor $^{32}$, antimalarial ${ }^{33}$, Vibrio fischeri quorum sensing regulator ${ }^{34}$, selective antagonists of the TP $\alpha$ and

Rasayan J. Chem., 11(3), 1334-1338(2018)

http://dx.doi.org/10.31788/RJC.2018.1133084

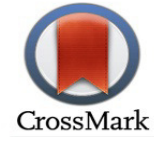


TP $\beta$ isoforms of the human thromboxane A2 receptor ${ }^{35}$, reversible inhibitors of human steroid sulfatase ${ }^{36}$, $\mathrm{K}_{\mathrm{ATP}}$-channel openers ${ }^{37}$, antagonists of the ANG II AT1 receptors ${ }^{38}$, inhibitors of Acyl-CoA: cholesterol O-Acyltransferase ${ }^{39}$, inhibitors of aldehyde dehydrogenase ${ }^{40}$, non-competitive Inhibitor of acetohydroxyacid synthase from Mycobacterium tuberculosi ${ }^{41}$, cancer chemotherapeutic ${ }^{42}$, antitumor ${ }^{43}$, oncolytic $^{44}$, diuretic ${ }^{45}$, selective $\beta 3$ adrenergic receptor agonist ${ }^{46}$, and vasodilator ${ }^{47}$. Therefore, a series of novel hybrid sulfonylurea-linked chalconoids (SC1-28) were designed, synthesized, characterized and earlier reported from our laboratories as potential cytotoxic and antimicrobial agents ${ }^{48}$. It is proved from the literature that the compounds containing neither sulfonylurea nor chalcone moieties often shows significant antidiabetic activity profiles.

\section{EXPERIMENTAL}

In the present investigation, a series of novel hybrid sulfonylurea-linked chalconoids (SC1-28) ${ }^{48}$ shown in (Fig.-1) were evaluated them for in vivo antihyperglycemic potential using streptozotocin-induced type 2 diabetic rats ${ }^{49}$. The experimental protocol has been approved by the Institutional Animal Ethics Committee (IAEC) and by the Animal Regulatory Body of the Government. (Regd. No. 516/01/A/CPCSEA). The direct comparison of the antihyperglycemic effect of the sulfonylurea-linked chalcones SC1-28 is made rather difficult by the fact that not only the maximal decrease of the blood glucose level produced by the standard doses of the compound but also the dose-response curves vary from compound to compound.

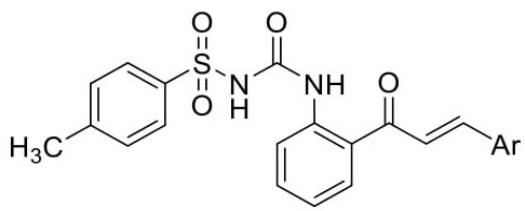

\begin{tabular}{llll}
\hline Compound & Ar & Compound & Ar \\
\hline SC1 & $\mathrm{C}_{6} \mathrm{H}_{5}$ & SC15 & $3-\mathrm{NO}_{2} \mathrm{C}_{6} \mathrm{H}_{4}$ \\
SC2 & $4-\mathrm{MeC}_{6} \mathrm{H}_{4}$ & $\mathbf{S C 1 6}$ & $5-\mathrm{OH}, 2-\mathrm{NO}_{2} \mathrm{C}_{6} \mathrm{H}_{3}$ \\
$\mathbf{S C 3}$ & $4-\mathrm{NMe}_{2} \mathrm{C}_{6} \mathrm{H}_{4}$ & $\mathbf{S C 1 7}$ & $3-\mathrm{FC}_{6} \mathrm{H}_{4}$ \\
$\mathbf{S C 4}$ & $3-\mathrm{OMeC}_{6} \mathrm{H}_{4}$ & $\mathbf{S C 1 8}$ & $4-\mathrm{FC}_{6} \mathrm{H}_{4}$ \\
SC5 & $4-\mathrm{OMeC}_{6} \mathrm{H}_{4}$ & $\mathbf{S C 1 9}$ & $2-\mathrm{ClC}_{6} \mathrm{H}_{4}$ \\
SC6 & $3,4-\mathrm{diOMeC}_{6} \mathrm{H}_{3}$ & $\mathbf{S C 2 0}$ & $4-\mathrm{ClC}_{6} \mathrm{H}_{4}$ \\
SC7 & $2,4-\mathrm{diOMeC}_{6} \mathrm{H}_{3}$ & $\mathbf{S C 2 1}$ & $2,4-\mathrm{diClC}_{6} \mathrm{H}_{3}$ \\
SC8 & $3,4,5-\mathrm{triOMeC}_{6} \mathrm{H}_{2}$ & $\mathbf{S C 2 2}$ & $3-\mathrm{BrC}_{6} \mathrm{H}_{4}$ \\
$\mathbf{S C 9}$ & $2-\mathrm{OHC}_{6} \mathrm{H}_{4}$ & $\mathbf{S C 2 3}$ & $4-\mathrm{Allyl}_{4}-\mathrm{OC}_{6} \mathrm{H}_{4}$ \\
SC10 & $3-\mathrm{OHC}_{6} \mathrm{H}_{4}$ & $\mathbf{S C 2 4}$ & Phenylethene-yl \\
SC11 & $4-\mathrm{OHC}_{6} \mathrm{H}_{4}$ & $\mathbf{S C 2 5}$ & Pyrrol-2-yl \\
SC12 & $3-\mathrm{OEt}_{4} 4-\mathrm{OHC}_{6} \mathrm{H}_{3}$ & $\mathbf{S C 2 6}$ & Pyridin-3-yl \\
SC13 & $3-\mathrm{OMe}_{4} 4-\mathrm{OHC}_{6} \mathrm{H}_{3}$ & $\mathbf{S C 2 7}$ & Pyridin-4-yl \\
SC14 & $2-\mathrm{NO}_{2} \mathrm{C}_{6} \mathrm{H}_{4}$ & $\mathbf{S C 2 8}$ & Anthracen-9-yl
\end{tabular}

Fig.-1: Chemical Structures of the Sulfonylurea-linked Chalconoid (SC1-28) ${ }^{48}$

\section{RESULTS AND DISCUSSION}

The results of in vivo antihyperglycemic activity of the synthesized sulfonylurea-linked chalcones (SC128) showed that all the compounds were found to possess moderate to potential ability to reduce blood glucose levels in streptozotocin-induced type 2 diabetic rats. We consequently found that the blood glucose reduction ability of the titled compounds (SC1-28) was followed a dose-dependent manner in their antihyperglycemic activity. Among all the tested compounds, compound SC21 (Fig.-2) showed 
significant antihyperglycemic activity at various doses such as 10,30 and $50 \mathrm{mg} / \mathrm{kg}$ b.w with percentage blood glucose reduction values $14.66 \pm 0.27 \%, 20.18 \pm 1.34 \%$ and $21.78 \pm 2.61 \%$, respectively at $4 \mathrm{~h}$. Similarly, compound SC5 also showed promising antihyperglycemic activity. In the same way, compounds such as SC13, SC19, SC4, SC3, SC11, SC27, SC1, SC22, SC9, SC10, SC10, SC26, SC20, SC23 and SC8 exhibited a moderate range of antihyperglycemic activity at all the doses. The other compounds such as SC12, SC24, SC7, SC6, SC15, SC2, SC25, SC16, SC14, SC17, SC28 and SC18 showed lower level of antihyperglycemic activity when compared to that of the reference drug gliclazide with percentage blood glucose reduction values $40.51 \pm 1.46 \%$ and $45.34 \pm 3.02 \%$ at dose $2 \mathrm{mg} / \mathrm{kg}$ b.w.<smiles>Cc1ccc(S(=O)(=O)NC(=O)Nc2ccccc2C(=O)/C=C/c2ccc(Cl)cc2Cl)cc1</smiles>

Fig.-2: Chemical Structure of the Sulfonylurea-linked Chalconoid (SC21).

It is noteworthy to establish the structure-activity relationships (SARs) for the observed antihyperglycemic activity of sulfonylurea-linked chalcones SC1-28. It is clear from the results of antihyperglycemic activity that the structural requirements for retaining (or enhancing) antihyperglycemic property in sulfonylurea-linked chalcones SC1-28 are not inflexible. As such, the following are the conventional SARs. The $\alpha, \beta$-unsaturated ketone and sulfonylurea-linker moieties are the vital structural pharmacophores for maintaining the antihyperglycemic activity. It is remarkable that an enhanced level of activity was observed when the phenyl ring of $\alpha, \beta$-unsaturated carbonyl system is substituted with different functional groups and decreased by some other substituents. The order of activity was SC5 (4$\left.\mathrm{OCH}_{3}\right)>\mathrm{SC} 13\left(3-\mathrm{OCH}_{3}, 4-\mathrm{OH}\right)>\mathrm{SC} 19(2-\mathrm{Cl})>\mathrm{SC} 4\left(3-\mathrm{OCH}_{3}\right)>\mathrm{SC} 3\left(\mathrm{~N}\left(\mathrm{CH}_{3}\right)_{2}\right)>\mathrm{SC} 11(4-\mathrm{OH})>$ SC22 $(3-\mathrm{Br})>\mathrm{SC} 9(2-\mathrm{OH})>\mathrm{SC} 10(3-\mathrm{OH})>\mathrm{SC} 20(4-\mathrm{Cl})>\mathrm{SC} 23(4-\mathrm{Allyl}$ loxy $)>\mathrm{SC} 8\left(3,4,5-\mathrm{triOCH}_{3}\right)>$ $\mathrm{SC} 12\left(3-\mathrm{C}_{2} \mathrm{H}_{5}, 4-\mathrm{OH}\right)>\mathrm{SC} 24$ (phenylethenyl) $>\mathrm{SC} 7\left(2,4-\mathrm{diOCH}_{3}\right)>\mathrm{SC} 6\left(3,4-\mathrm{diOCH}_{3}\right)>\mathrm{SC} 15\left(3-\mathrm{NO}_{2}\right)$ $>\mathrm{SC} 2\left(4-\mathrm{CH}_{3}\right)>\mathrm{SC} 16\left(5-\mathrm{OH}, 2-\mathrm{NO}_{2}\right)>\mathrm{SC} 14\left(2-\mathrm{NO}_{2}\right)>\mathrm{SC} 17(3-\mathrm{F})>\mathrm{SC} 18$ (4-F), respectively. An ortho and para substitution on the phenyl ring of $\alpha, \beta$-unsaturated carbonyl system with less electronegative halogens compared to fluorine, such as chloro may significantly enhance the activity as seen in the case of compound SC21. A para-substitution on the phenyl ring of $\alpha, \beta$-unsaturated carbonyl system with electron-donating groups possibly will increase the activity. A para-substitution on the phenyl ring of $\alpha, \beta$-unsaturated carbonyl system with hydroxyl group relevant for maintaining activity. The replacement of phenyl ring with a pyridine-4-yl ring as in compound SC27 exhibited a significant increase in activity compared to the compounds possessing other aromatic or heteroaromatic ring systems, the order of activity was SC26 (pyridin-3-yl) > SC25 (pyrrole) > SC28 (anthracen-9-yl), respectively.

\section{CONCLUSION}

In summary, we have evaluated a series of sulfonylurea-linked chalconoids and among the compounds tested $\alpha, \beta$-unsaturated carbonyl system and sulfonylurea moieties were appeared to be pivotal to retain the antihyperglycemic potential of this chemotype. This study would be the remarkable implications to develop new hybrid scaffolds consisting of either chalcone or sulfonylurea chemical pharmacophores in their basic nucleus.

\section{ACKNOWLEDGMENT}

One of the authors D. Bhagya Raju is thankful to the Principal, Andhra University College of Pharmaceutical Sciences for providing animal ethics clearance and also the facilities to carry out his research work. 
RASĀYAN $J$. Chem.

Vol. 11 | No. 3 |1334 - 1338 | July - September | 2018

\section{REFERENCES}

1. P. Insel, S. Amara, T. Blaschke and U. Meyer, Annu. Rev. Pharmacol Toxicol., 58, 33(2018), DOI:10.1146/annurev-pharmtox-092617-121952

2. M. Jankowska, A. Qureshi, P. Barany, O. Heimburger, P. Stenvinkel and B. Lindholm, Nephrology, 23, 31(2017), DOI:10.1111/nep.12927

3. K. Sas, J. Lin, T. Rajendiran, T. Soni, V. Nair, L. Hinder, H. Jagadish, T. Gardner, S. Abcouwer, F. Brosius, E. Feldman, M. Kretzler, G. Michailidis and S. Pennathur, J. Lipid. Res., 59, 173(2017), DOI:10.1194/jlr.m077222

4. V. Mamakou, I. Eleftheriadou, N. Katsiki, K. Makrilakis, K. Tsioufis and N. Tentolouris, Current Vascular Pharmacology, 16,(2017), DOI:10.2174/1570161115666171010122332

5. J. Nam and Y. Lee, Molecules, 22, 1750(2017), DOI:10.3390/molecules22101750

6. J. Fonseca, S. Marques, P. Silva, P. Brandão, H. Cidade, M. Pinto and H. Bousbaa, Molecules, 21, (2016), DOI:10.3390/molecules21080982

7. S. Zhang, D. Fu, X. Yue, Y. Liu, J. Song, H. Sun, H. Liu and Y. Zhang. Molecules, 21, 653(2016), DOI: 10.3390/molecules21050653

8. M. El-Hashash, S. Rizk and S. Atta-Allah. Molecules, 20, 22069(2015), DOI: 10.3390/molecules201219827

9. Y. Chen, C. Chang, C. Chang, P. Chen, Y. Lee, C. Chern and J. Tsai. Molecules, 20, 12512(2015), DOI: $10.3390 /$ molecules200712512

10. Z. Wan, D. Hu, P. Li, D. Xie and X. Gan. Molecules, 20, 11861(2015), DOI: $10.3390 /$ molecules200711861

11. J. Wu, C. Cheng, L. Shen, Z. Wang, S. Wu, W. Li, S. Chen, R. Zhou and P. Qiu. Int J Mol Sci, 15, 18525 (2014), DOI:10.3390/ijms151018525

12. E. Otero, S. Vergara, S. Robledo, W. Cardona, M. Carda, I. Vélez, C. Rojas and F. Otálvaro. Molecules, 19, 13251(2014), DOI:10.3390/molecules190913251

13. Y. Chen, W. Wang, Y. Wang, Z. Lin, C. Wen and C. Chern. Molecules, 18, 2052(2013), DOI:10.3390/molecules18022052

14. Y. Pan, Y. Chen, Q. Li, X. Yu, J. Wang and J. Zheng. Molecules, 18, 1693(2013), DOI:10.3390/molecules 18021693

15. J. Kang, J. Cho, M. Curtis-Long, H. Ryu, J. Kim, H. Kim, H. Yuk, D. Kim and K. Park. Molecules, 18, 140 (2012), DOI: 10.3390/molecules 18010140

16. A. Escobar-Ramos, C. Lobato-García, A. Zamilpa, A. Gómez-Rivera, J. Tortoriello and M. González-Cortazar. Molecules, 22, 1405(2017), DOI:10.3390/molecules22091405

17. M. Kucerova-Chlupacova, V. Vyskovska-Tyllova, L. Richterova-Finkova, J. Kunes, V. Buchta, M. Vejsova, P. Paterova, L. Semelkova, O. Jandourek and V. Opletalova. Molecules, 21, 1421(2016), DOI: $10.3390 /$ molecules21111421

18. T. Tran, T. Nguyen, N. Nguyen, D. Nguyen, T. Nguyen, M. Le and K. Thai. Appl Sci, 6, 198(2016), DOI:10.3390/app6070198

19. T. Ventura, S. Calixto, B. Abrahim-Vieira, A. Souza, M. Mello, C. Rodrigues, L. Miranda, R. de Souza, I. Leal, E. Lasunskaia and M. Muzitano. Molecules, 20, 8072(2015), DOI: $10.3390 /$ molecules20058072

20. N. Song, J. Kim, J. Park, J. Kim, H. Kang, E. Lee, Y. Kang, J. Son, S. Seo, Y. Heo and K. Lee, Licochalcone A. Int J Mol Sci, 16, 4453(2015), DOI:10.3390/ijms16034453

21. H. Suwito, Jumina, Mustofa, P. Pudjiastuti, M. Fanani, Y. Kimata-Ariga, R. Katahira, T. Kawakami, T. Fujiwara, T. Hase, H. Sirat and N. Puspaningsih. Molecules, 19, 21473(2014), DOI:10.3390/molecules191221473

22. E. Szliszka, D. Jaworska, M. Ksek, Z. Czuba and W. Król. Int J Mol Sci, 13, 15343(2012), DOI:10.3390/ijms131115343

23. G. da Silva, M. da Silva, E. Souza, A. Barison, S. Simões, F. Varotti, L. Barbosa, G. Viana and J. Villar. Molecules, 17, 10331(2012), DOI:10.3390/molecules170910331

24. S. Syam, S. Abdelwahab, M. Al-Mamary and S. Mohan. Molecules, 17, 6179(2012), DOI:10.3390/molecules17066179 


\section{RASĀYAN J. Chem.}

Vol. 11 | No. 3 |1334 - 1338 | July - September | 2018

25. E. Szliszka, Z. Czuba, B. Mazur, A. Paradysz and W. Krol.Molecules, 15, 5336(2010), DOI:10.3390/molecules15085336

26. H. Zhang, Y. Zhang, G. Wu, J. Zhou, W. Huang and X. Hu. Bioorg Med Chem Lett, 19, 1740(2009), DOI:10.1016/j.bmcl.2009.01.082

27. S. Fukuen, M. Iwaki, A. Yasui, M. Makishima, M. Matsuda and I. Shimomura. J Bio Chem, 280, 23653 (2005), DOI:10.1074/.jbc.m412113200

28. A. Chavan and N. Pai. Journal of the Chin Chem Soc, 54, 771(2007), DOI:10.1002/jccs.200700111

29. S. Itoh, K. Ohta, T. Yamawaki and Y. Ishida. $J$ Pest Sci, 26, 162(2001), DOI:10.1584/jpestics.26.162

30. J. Burch, J. Farand, J. Colucci, C. Sturino, Y. Ducharme, R. Friesen, J. Lévesque, S. Gagné, M. Wrona, A. Therien, M. Mathieu, D. Denis, E. Vigneault, D. Xu, P. Clark, S. Rowland and Y. Han. Bioorg Med Chem Lett, 21, 1041(2011), DOI:10.1016/j.bmcl.2010.12.014

31. M. Lo, H. Chobanian, O. Palyha, Y. Kan, T. Kelly, X. Guan, M. Reitman, J. Dragovic, K. Lyons, R. Nargund and L. Lin. Bioorg Med Chem Lett, 21, 2040(2011), DOI:10.1016/j.bmcl.2011.02.011

32. M. Winters, C. Crysler, N. Subasinghe, D. Ryan, L. Leong, S. Zhao, R. Donatelli, E. Yurkow, M. Mazzulla, L. Boczon, C. Manthey, C. Molloy, H. Raymond, L. Murray, L. McAlonan and B. Tomczuk. Bioorg Med Chem Lett, 18, 1926(2008), DOI:10.1016/j.bmcl.2008.01.127

33. C. Leon, J. Rodrigues, N. Gamboa de Dominguez, J. Charris, J. Gut, P. Rosenthal and J. Dominguez. ChemInform, 38, (2007), DOI:10.1002/chin.200741072

34. M. Frezza, L. Soulère, S. Reverchon, N. Guiliani, C. Jerez, Y. Queneau and A. Doutheau. Bioorg Med Chem Lett, 16, 3550(2008), DOI:10.1016/j.bmc.2008.02.023

35. J. Hanson, J. Dogné, J. Ghiotto, A. Moray, B. Kinsella and B. Pirotte. J Med Chem, 50, 3928(2007), DOI:10.1021/jm070427h

36. P. Lehr, A. Billich, B. Wolff and P. Nussbaumer. Bioorg Med Chem Lett, 15, 1235(2005), DOI:10.1016/j.bmcl.2004.11.069

37. E. Salamon, R. Mannhold, H. Weber, H. Lemoine and W. Frank. J Med Chem, 45, 1086(2002), DOI:10.1021/jm010999g

38. H. Heitsch, R. Becker, H. Kleemann and A. Wagner. Bioorg Med Chem., 5, 673(1997), DOI:10.1016/s0968-0896(97)00012-6

39. J. Picard, P. O'Brien, D. Sliskovic, M. Anderson, R. Bousley, K. Hamelehle, B. Krause and R. Stanfield. J Med Chem, 39, 1243 (1996), DOI:10.1021/jm9509455

40. M. Lee, J. Elberling and H. Nagasawa. J Med Chem, 35, 3641 (1992), DOI:10.1021/jm00098a007

41. K. J. Choi, K. M. Noh, J. D. Choi, J.S. Park. Bull Kor Chem Soc, 27, 1697(2006), DOI:10.5012/bkcs.2006.27.10.1697

42. F. Mohamadi, M. Spees and G. Grindey. J Med Chem, 35, 3012 (1992), DOI:10.1021/jm00094a013

43. J. Howbert, C. Grossman, T. Crowell, B. Rieder, R. Harper, K. Kramer, E. Tao, J. Aikins and G. Poore. J Med Chem, 33, 2393 (1990), DOI:10.1021/jm00171a013

44. J. Toth, G. Grindey, W. Ehlhardt, J. Ray, G. Boder, J. Bewley, K. Klingerman, S. Gates, S. Rinzel, R. Schultz, L. Weir and J. Worzalla. J Med Chem, 40, 1018 (1997), DOI:10.1021/jm9606731

45. B. Loev and K. Shader. J Med Chem Lett, 11, 1250 (1968), DOI:10.1021/jm00312a603

46. D. Uehling, K. Donaldson, D. Deaton, C. Hyman, E. Sugg, D. Barrett, R. Hughes, B. Reitter, K. Adkison, M. Lancaster, F. Lee, R. Hart, M. Paulik, B. Sherman, T. True and C. Cowan. J Med Chem, 45, 567 (2002), DOI:10.1021/jm0101500

47. S. Khelili, G. Leclerc, G. Faury and J. Verdetti. Bioorg Med Chem, 3, 495(1995), DOI:10.1016/0968-0896(95)00040-n

48. 3.V. Avupati, R. Yejella, G. Guntuku and P. Gunta. Bioorg Med Chem Lett, 22, 1031(2012), DOI:10.1016/j.bmcl.2011.11.125

49. V. Avupati, R. Yejella, A. Akula, G. Guntuku, B. Doddi, V. Vutla, S. Anagani, L. Adimulam and A. Vyricharla. Bioorg Med Chem Lett, 22, 6442 (2012), DOI:10.1016/j.bmcl.2012.08.052

[RJC-3084/2018] 